\title{
LIFE CYCLE COST ANALYSIS IN DETERMINING OPTIMUM PIPE INSULATION THICKNESS WITH AIR GAP FOR DIFFERENT CLIMATE CONDITIONS
}

\author{
*Yusuf BAŞOĞUL \\ Department of Mechanical Engineering, Adıyaman University, Turkey, ybasogul@adiyaman.edu.tr \\ (iD) https://orcid.org/0000-0002-9668-6654
}

Received: 11.02.2018, Accepted: 06.06.2018

*Corresponding author

DOI:10.22531/muglajsci.422979

\section{Abstract}

This study is about determining air gap, insulation material in pipes between $50 \mathrm{~mm}$ and $1000 \mathrm{~mm}$ in mechanical installation, and determining optimum insulation thickness, energy saving and payback period in cases where both are being used. For this calculation, life cycle cost analysis containing heating degree day has been used. Even though Afyon province climate conditions have been used as the case study, the study has been expanded for cold, temperate and warm climate conditions. This made it possible to make comparative assessments for insulation thickness, air gap, pipe diameter and heating degree day values. In $50 \mathrm{~mm}$ and $1000 \mathrm{~mm}$ pipes using air gap, the optimum insulation thickness was reduced by $81 \%$ and $39 \%$ respectively. It is recommended to use air gap in mild climates and to use insulation in cold climates. When insulation with air gap is applied, optimum insulation thickness is reduced, and in pipes with greater diameter energy cost saving is increased while in pipes with smaller diameter the payback period is reduced.

Keywords: Pipe insulation, Air gap, Life cycle cost analysis, Optimum insulation thickness

\section{FARKLI İKLIMM ŞARTLARI İÇİN HAVA BOŞLUKLU OPTIMUMM BORU YALITIM KALINLIĞININ BELİRLENMESINNDE YAŞAM DÖNGÜSÜ MALIYET ANALİZI}

\section{Öz}

Bu çalışma mekanik tesisatta $50 \mathrm{~mm}$ ile $1000 \mathrm{~mm}$ arasındaki borularda hava boşluğu, yalıtım malzemesi ve her ikisinin kullanıldığı durumlardaki optimum yalıtım kalınlı̆̆ı, enerji tasarrufu ve geri dönüş süresinin belirlenmesi ile ilgilidir. Bu hesaplama için ısıtma derece günler içerikli yaşam döngüsü maliyet analizi kullanılmıştır. Durum çalışması olarak Afyon ili iklim şartları kullanılmasına rağmen çalışma soğuk, ılıman ve sıcak iklim şartları için de genişletilmiştir. Böylece yalıtım kalınlığı, hava boşluğu, boru çapı ve ısıtma derece gün değerlerine göre karşılaştırmalı değerlendirmeler yapılmıştır. Hava boşluğunun kullanıldığı 50 mm ve 1000 mm'lik borularda optimum yalıtım kalınlığı sırasıyla \%81 ve \%39 düşmüştür. Ilık iklimlerde hava boşluğunun ve soğuk iklimlerde ise yalıtımın kullanılması tavsiye edilir. Hava boşluklu yalıtım uygulandığında optimum yalıtım kalınlığını düşürmekle birlikte büyük çaplı borularda enerji maliyet tasarrufu artarken küçük çaplı borularda geri dönüşs süresi düşmektedir.

Anahtar Kelimeler: Boru yalıtımı, Hava boşluğu, Yaşam döngüsü maliyet analizi, Optimum yalıtım kalınlığı

Cite

Başoğul, Y., (2018). "Life cycle cost analysis in determining optimum pipe insulation thickness with air gap for different climate conditions", Mugla Journal of Science and Technology, 4(1), 89-101.

\section{Introduction}

Energy saving is an indispensable strategy in the world due to the reduction of fossil-based energy resources and negative environmental effects. In the industry, construction and transport sectors, biggest consumers of energy, several savings strategies are being implemented nowadays. The most important one of these is heat loss. And the most meaningful method of reducing heat loss particularly in buildings, mechanical installation, industry, localised heating/cooling is to make an insulation material selection and to decide on the insulation thickness. This way, the insulation of pipes will provide less heat loss and greater savings. As the insulation thickness increases savings increase but at the same time investment cost also increase. In this sense, it is necessary to do an optimum insulation thickness calculation when determining the type and thickness of heat insulation material.

Life cycle cost (LCC) analysis is being effectively used generally in energy technologies and building/mechanical installation works. It is used even more particularly in insulation applications. LCC analysis indicates that net savings can be generated throughout the life cycle of the pipe system by spending at early stages on the insulation of the pipe system transmitting the heat required for heating [1]. For LCC analysis in insulation applications, it is highly important to determine the annual energy consumption to be 
transmitted through the pipes. The easiest and most effective way of estimating the annual energy consumption of a building is to determine the amount of annual heating degree days by using the hourly data. Knowing the total value of heating day degrees is important for calculating the energy needs required for the heating of buildings. On the other hand, the heat load need of the buildings is being transmitted through pipes in thermal systems. As a result of the losses during this transmission of heat equalling to heat load requirement resulting from the piping system, it is possible to calculate the optimum insulation thickness in pipes. However, in order to do this, it is necessary to define many parameters and know their impacts.

In the literature there are many studies optimizing insulation thickness by using air gap and/or insulation in external walls of buildings. Mohsen and Akash [2] who researched the energy savings in a study using polystyrene, rock wool and air gap as insulation material. According to their results, they showed polystyrene provided $36 \%$ energy savings, rock wool 34\% and air gap $5.4 \%$. Suman and Srivastava [3] determined coefficient of overall thermal conduction of combined materials with and without air gap. The results reported that about $80 \%$ of $U$-value is reduced by providing a $3.8 \mathrm{~cm}$ air gap between two layers of a combined wall section. Mahlia and Iqbal [4] have reported that if air gaps between $2 \mathrm{~cm}$, $4 \mathrm{~cm}$ and $6 \mathrm{~cm}$ are taken and optimum thicknesses of various insulation materials are determined, energy consumption and emission could be reduced by $65-77 \%$ when compared to a wall without any air gaps. Kurt [5] has studied the effect of air gap in composite external walls in Karabük/Turkey on optimum insulation thickness, energy saving, total cost, $\mathrm{CO}_{2}$ and $\mathrm{SO}_{2}$ emissions. He has reported 30\% savings over the total cost in $2 \mathrm{~cm}, 4 \mathrm{~cm}$ and $6 \mathrm{~cm}$ air gaps when compared to walls without air gaps. Dasdemir [6] investigated the effects of air gaps on the optimum insulation thickness, energy savings and emissions of $\mathrm{CO}_{2}$ and $\mathrm{SO}_{2}$ in composite wall construction. The results show that when $4 \mathrm{~cm}$ air gap is used, the energy saving and the $\mathrm{CO}_{2}$ and $\mathrm{SO}_{2}$ emissions were decreased by $81 \%$ and $80 \%$, respectively. Ridouane and Bianchi [7] described the computational fluid dynamic model to evaluate the thermal performance of uninsulated or partially filled wall cavities for conduction, convection and radiation. They reported that for a partially filled cavity a small air gap could lead to a significant reduction in resistance. Mahlia et al. [8] evaluated the energy savings of air gap in wall construction for building thermal insulation materials on the energy consumption of air-conditioning for cooling based on tropical climate conditions in Malaysia. They found that additional $0.64 \% / \mathrm{m}^{2}$ wall of life cycle cost savings can be achieved by applying $6 \mathrm{~cm}$ air gap with the selected insulation at optimal thickness. Cai and Cremaschi [9] developed a new model for predicting the thermal conductivity of closed-cell pipe insulation systems operating below ambient conditions in both dry and wet conditions with moisture ingress.
The model included joint sealant effects and the impact of the air gap between the insulation and the pipe wall on the bottom section of the pipe insulation system. Faris et al. [10] evaluated numerically the effects of air gap thickness between the glass and wall on the thermal parameters of Trombe wall in Baghdad wintertime conditions. They showed that there was a remarkable temperature increase inside the room. Erturk [11] used an air gap with insulation material in buildings in Ankara/Turkey and calculated the optimum insulation thickness, total costs, energy savings and payback period. For flue gas release calculations, total external wall surface areas and populations of the buildings in the province were noted and an annual fuel consumption emission approach per person was developed. When air gap is used, total cost and payback period reduce by $38 \%$ and $9 \%$ respectively, while annual gains increase by $96 \%$. Compared to a building without insulation, adding $4 \mathrm{~cm}$ XPS and $4 \mathrm{~cm}$ air gap was determined to reduce $\mathrm{CO}_{2}$ release by $82 \%$.

Reviewing the literature and the above mentioned studies did not yield any studies on the use of air gap and/or insulation in pipes. Therefore, the objective of this study is to analyse the effects of using air gap on optimum insulation thickness, energy cost, saving and payback period in insulated and non-insulated pipes. Another objective of the study is to study the effects of air gap in pipes insulated for cold, mild and warm climates.

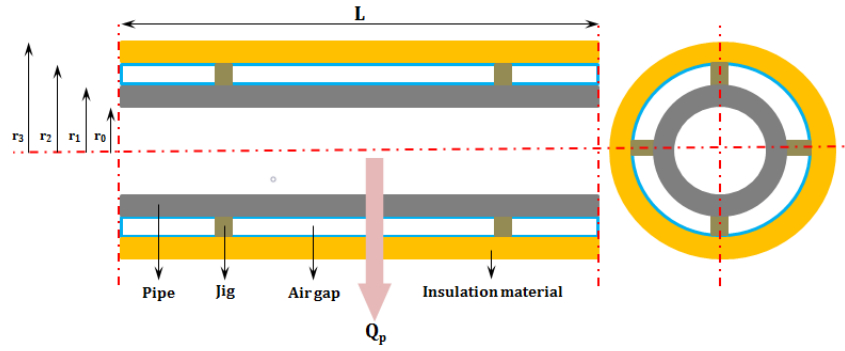

Figure 1. A sectional view of an insulated air gapped pipe.

\section{Material and Method}

Pipes are important components in oil pipe lines, localized heating/cooling pipe lines, steam transmission pipe lines, fire protection pipe lines and industrial and chemical pipe lines. Therefore, it is necessary to reduce the heat changes and heat losses in pipes. This is how heat insulation is being applied. The objective of this study is to look for a method that would reduce heat losses in pipe insulation. This method is to assume that there is a hollow layer between pipe and insulation material. In this hollow layer on the pipe, an air gap will be left where natural transmission is ignored. Thus, when the natural transmission in the air gap is ignored, the mathematical calculation of the air gap will be similar to that of the insulation. A visual on indicating the use of air gap and insulation in mechanical installation is presented in Fig. $1.0 \mathrm{~cm}$ means no air gap has been used and from $1 \mathrm{~cm}$ to $5 \mathrm{~cm}$, air gaps with $1 \mathrm{~cm}$ intervals have been assumed. Some acceptances have been used for the calculations. For the case study, Afyon/Turkey has been 
selected, and EPS has been used as insulation material and fuel-oil has been used as fuel. It has been accepted that throughout the pipe, water was running at a fixed temperature of $80{ }^{\circ} \mathrm{C}$, under stable state stable flow control volume conditions with a fixed velocity of 0.8 $\mathrm{m} / \mathrm{s}$, without any reductions in temperature and pressure values and a fixed air speed of $0.2 \mathrm{~m} / \mathrm{s}$ in the external environment (channel, duct etc.) and a fixed ambient temperature of $10^{\circ} \mathrm{C}$.

The heat loss from within the pipe to the external environment can be calculated as

$Q_{p}=U\left(T_{a d}-T_{o}\right)$

where $U, T_{a d}$ and $T_{o}$ denote total heat transfer coefficient, the average design temperature of the fluid inside the pipe, and the environmental temperature outside the pipe, respectively.

The annual heat amount carried in thermal systems may be determined using heat degree days [1,12-16]. For hourly data, annual heating degree day $(H D D)$ value is

$H D D=(1$ year $) \sum_{1}^{365}\left(T_{b}-T_{o}\right)$

where $T_{b}$ and $T_{0}$ denote base temperature and external environmental temperature, respectively.

Using $H D D$, the annual energy amount transferred by fluid within the pipe with the heating process is assumed to be equal to the annual heat losses from the pipe to the external environment, and it may be generally expressed as $[1,12-16]$ :

$Q_{p, l o s s}=86,400 \mathrm{HDDU}_{p}$

where $U_{p}$ denotes the total heat transfer coefficient for all pipe layers. For air gapped and insulated pipe layers (internal fluid + pipe + air gap + insulation material + external fluid), the $U_{p}$ is below:

$\frac{1}{U_{p, a g-i n s}}=\frac{1}{h_{i} A_{i}}+\frac{\ln \left(\frac{r_{1}}{r_{0}}\right)}{2 \pi L k_{p}}++\frac{\ln \left(\frac{r_{2}}{r_{1}}\right)}{2 \pi L k_{a g}}+\frac{\ln \left(\frac{r_{3}}{r_{2}}\right)}{2 \pi L k_{i n s}}+\frac{1}{h_{o} A_{o}^{\prime}}$

where $A_{i}=2 \pi L r_{0}$ and $A_{o}^{\prime}=2 \pi L r_{3}$. Here, the $h_{i}$ and $h_{0}$ can be calculated as [17]:

$h_{i}=0.023 \operatorname{Re}^{0.8} \operatorname{Pr}^{0.4} \frac{k_{i}}{2 r_{0}}$

and

$$
\begin{aligned}
h_{o}= & 11.58(1 / d)^{0.2}\left[2 /\left(\left(T_{m s}+T_{o}\right)-546.3\right)\right]^{0.181} \\
& \left(T_{m s}-T_{o}\right)^{0.266}\left(1+2.86 V_{\text {air }}\right)^{0.5}
\end{aligned}
$$

where $d=2(r 2+\delta)[18]$.

The amount of annual fuel consumption is:

$m_{f}=\frac{86,400 H D D U_{p}}{H_{u} \eta_{h s}}$

where $H_{u}$ and $\eta_{h s}$ denote the lower heat value of fuel and its combustion system' efficiency.

For life cycle cost (LCC) analysis used to assess the economics of the insulation, the life cycle energy rate $\left(P_{1}\right)$ and life cycle expense rate $\left(P_{2}\right)$ may be defined as follows:

$$
\begin{aligned}
& P_{1}=\frac{N}{1+i}, \quad \text { if } \mathrm{i}=\mathrm{d} \\
& P_{1}=\frac{1}{(d-i)}\left[1-\left(\frac{1+i}{1+d}\right)^{N}\right], \quad \text { if } \mathrm{i} \neq \mathrm{d}
\end{aligned}
$$

As there is no maintenance and operating costs for insulation applications, note that $P_{2}$ is accepted as 0 .

For insulated pipes with air gap according to LCC analysis, the total cost $\left(C_{t}\right)$ and energy savings $(S)$ may be determined as below:

$C_{t}=P_{1} m_{f} C_{f}+P_{2} C_{I} V$

and

$S=P_{1} C_{f}^{\prime}-P_{2} C_{I} V$

where $C_{F}$ and $C_{I}$ denote unit cost of any fuel and cost of insulation material per unit volume. $C_{f}^{\prime}$ denotes the different between energy cost for the un-insulated and insulated pipes with air gap and $V=\pi\left(r_{3}^{2}-r_{2}^{2}\right) L$.

To calculate optimum insulation thickness, The $r_{\text {ins,opt }}$ value in Eq. (12) may be found using MATLAB program.

$$
\begin{aligned}
& 86,400 P_{1} H D D C_{f}\left(\frac{1}{k_{\text {ins }} r_{\text {ins }, \text { opt }}}-\frac{1}{h_{o} r_{\text {ins,opt }}^{2}}\right) \\
& H_{u} \eta_{h s}\left(\frac{1}{h_{i} r_{0}}+\frac{\ln \left(\frac{r_{1}}{r_{0}}\right)}{k_{\text {pipe }}}+\frac{\ln \left(\frac{r_{2}}{r_{1}}\right)}{k_{a g}}+\frac{\ln \left(\frac{r_{\text {ins }, \text { opt }}}{r_{2}}\right)}{k_{\text {ins }}}+\frac{1}{h_{o} r_{\text {ins,opt }}}\right)^{2} \\
& +2 P_{2} C_{i n s} r_{i n s, o p t}=0
\end{aligned}
$$

The energy cost savings $(S)$ and the payback period $\left(N_{p p}\right)$ are calculated with below:

$$
S=P_{1} \frac{86,400 \operatorname{HDD} C_{f}}{H_{u} \eta_{h s}}\left(U_{p, u n-i n s}-U_{p, q g-i n s}\right)-P_{2} C_{i n s} V
$$

and

$$
N_{p p}=\frac{C_{i n s} V(1+i)}{\frac{86,400 H D D C_{f}}{H_{u} \eta_{h s}}\left(U_{p, \text { un-ins }}-U_{p, a g-i n s}\right)} \quad \text { if } \mathrm{i}=\mathrm{d}
$$

$$
N_{p p}=\frac{\ln \left(1-\frac{C_{i n s} V(d-i)}{\frac{86,400 H D D C_{f}}{H_{u} \eta_{h s}}\left(U_{p, u n-i n s}-U_{p, a g-i n s}\right)}\right)}{\ln \left(\frac{1+i}{1+d}\right)}
$$

if $\mathrm{i} \neq \mathrm{d}$

\section{Results and Discussion}

This study calculates optimum insulation thickness, energy cost, energy saving and payback period for air gap and/or pipe insulation in pipes with various diameters by using life cycle cost (LCC) analysis. Hence, LCC analysis calculations have been performed in 
Afyon/Turkey for air gaps ranging between $1 \mathrm{~cm}$ and 5 $\mathrm{cm}$ between pipe and insulation material, by using fueloil fuel type, EPS insulation material and steel pipes with nominal diameters ranging between $50 \mathrm{~mm}$ and 1000 $\mathrm{mm}$ using the parameters given in Table 1. Findings acquired from the calculations have been presented and discussed below.

Table 1. The parameters used in the calculation.

\begin{tabular}{lc}
\hline Parameters & Values \\
\hline$H D D$ for $18^{\circ} \mathrm{C}$ & $2328{ }^{\circ} \mathrm{C}$ days \\
Fuel-oil & \\
$C_{F}$ & $0.7935 \$ / \mathrm{kg}$ \\
$H_{u}$ & $41.278 \times 10^{6} \mathrm{~J} / \mathrm{kg}$ \\
$\eta_{h s}$ & $80 \%$ \\
EPS (TS EN 13163) & \\
$\rho$ & $16 \mathrm{~kg} / \mathrm{m}^{3}$ \\
$k_{\text {ins }}$ & $0.036 \mathrm{~W} / \mathrm{m} \mathrm{K}^{3}$ \\
$C_{\text {ins }}$ & $32 \$ / \mathrm{m}^{3}$ \\
Stainless steel pipe & See Table 2 \\
Life cycle cost & \\
$i$ & $13 \%$ \\
$d$ & $6.5 \%$ \\
$N$ & $30 \mathrm{yr}$ \\
\hline
\end{tabular}

Table 2. Some properties of the stainless steel pipe used in the study.

\begin{tabular}{lcccc}
\hline $\begin{array}{l}\text { Nominal } \\
\text { pipe } \\
\text { size } \\
(\mathrm{mm})\end{array}$ & $\begin{array}{c}\text { Outer } \\
\text { diameter }\end{array}$ & $\begin{array}{c}\text { Wall } \\
\text { thickness }\end{array}$ & $\begin{array}{c}\text { Sch } \\
\text { No }\end{array}$ & $\begin{array}{c}\text { Unit } \\
\text { weight }\end{array}$ \\
\hline 50 & 60.3 & 3.91 & 40 & 5.44 \\
100 & 114.3 & 6.02 & 40 & 16.07 \\
200 & 219.1 & 8.18 & 40 & 42.55 \\
400 & 406.4 & 9.53 & 30 & 93.27 \\
600 & 610.0 & 9.53 & 20 & 141.12 \\
800 & 813.0 & 9.53 & 10 & 188.82 \\
1000 & 1016.0 & 9.53 & - & 236.53 \\
\hline
\end{tabular}

For stainless steel pipe (ANSI B 36.10), the density, melt temperature, conductivity and weight class are $7.99 \mathrm{~g} / \mathrm{cm}^{3}$, $1371-1399^{\circ} \mathrm{C}, 16.2 \mathrm{~W} / \mathrm{m}-\mathrm{K}$, and STD, respectively.

The effect of insulation thickness on annual cost for air gap in large and small diameter pipes is shown in Fig. 2. As shown in Figs. 2-a and 2-e with no air gap, there is a fall in energy costs with the use of insulation. When insulation is used, the insulation costs increase. The total annual cost which is the sum of energy cost and insulation cost has maximum value when insulation is not used in the first case, while it begins to reduce with the use of insulation. This reduction is minimum at the optimum insulation thickness as later added insulation thickness begins to increase total costs. With no insulation on small diameter pipes, the total cost is 46.4 $\$ / \mathrm{m}$-yr (Fig. 2-a). However, for large diameter pipes that value is $471 \$ / \mathrm{m}$-yr (Fig. 2-b). At optimum insulation thickness $(11.6 \mathrm{~cm}$ and $21.5 \mathrm{~cm}$ ) in both pipe types the total costs are found as $10.3 \$ / \mathrm{m}-\mathrm{yr}$ and $67.4 \$ / \mathrm{m}-\mathrm{yr}$, respectively. Using the optimum insulation thickness of
$11.6 \mathrm{~cm}$ of small diameter pipes, the total cost for large diameter pipes is $79.8 \$ / \mathrm{m}$-yr. Thus, this value $(79.8$ $\$ / \mathrm{m}-\mathrm{yr}$ ) and its value at optimum insulation thickness (67.4 \$/m-yr) are close to each other. The use of insulation on large diameter pipes lowers the total cost by $86 \%$. For small diameter pipes this decrease is $72 \%$. This indicates how important insulation is for large diameter pipes. Additionally, for small diameter pipes the insulation cost curve is not linear (Fig. 2-a), while for large diameter pipes this curve is linear (Fig. 2-e). The reason for this is the effect of the pipe geometry. As seen in Figs. 2-b, 2-c and 2-d showing the use of $1 \mathrm{~cm}, 3 \mathrm{~cm}$ and $5 \mathrm{~cm}$ air gaps, the use of an air gap with small diameter pipes has minimum annual costs of $8.6 \$ / \mathrm{m}-\mathrm{yr}, 6.7 \$ / \mathrm{m}$ yr and $5.5 \$ / m-y r$, respectively. Contrary to this, their optimum insulation thicknesses are $8.6 \mathrm{~cm}, 4.5 \mathrm{~cm}$ and $1.3 \mathrm{~cm}$. For large diameter pipes illustrated in Figs. 2-f, 2$\mathrm{g}$ and 2-h, the optimum insulation thicknesses are $19 \mathrm{~cm}$, $14 \mathrm{~cm}$ and $9.3 \mathrm{~cm}$ with annual costs of $63.3 \$ / \mathrm{m}-\mathrm{yr}, 55.4$ $\$ / \mathrm{m}-\mathrm{yr}$ and $48.1 \$ / \mathrm{m}-\mathrm{yr}$. Thus depending on whether there is an air gap or not, the annual costs for small diameter pipes reduced by $47 \%$ and for large diameter pipes this reduced by $29 \%$.

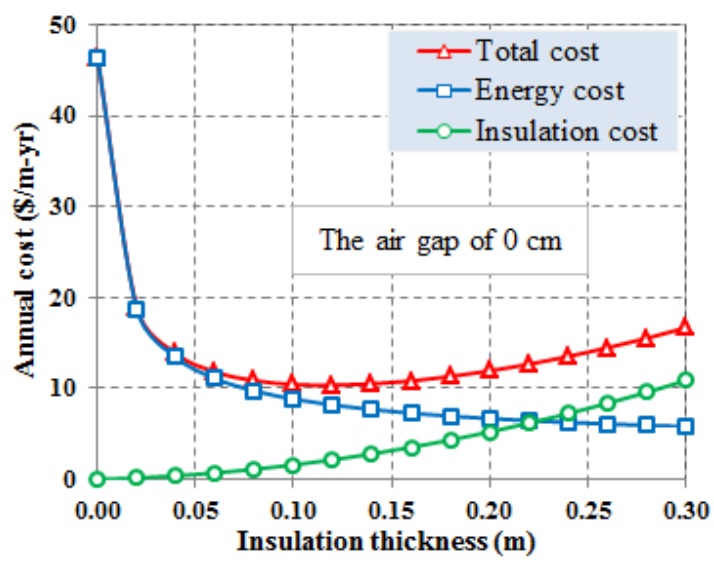

(a) $50 \mathrm{~mm}$ NPS

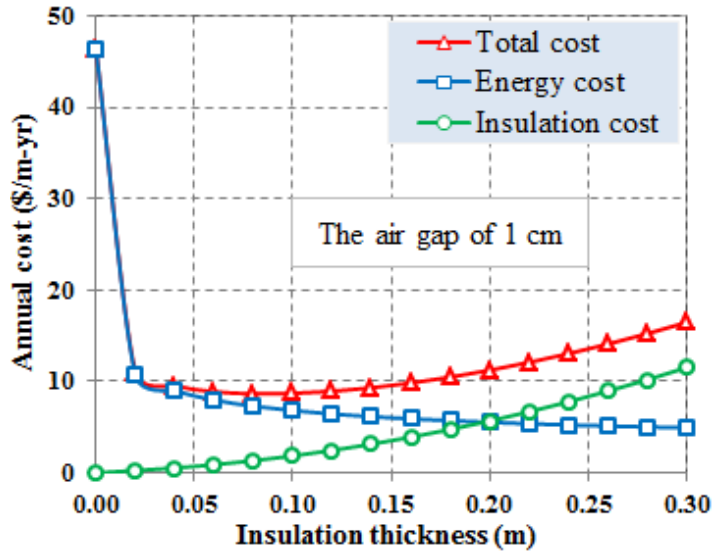

(b) $50 \mathrm{~mm}$ NPS 


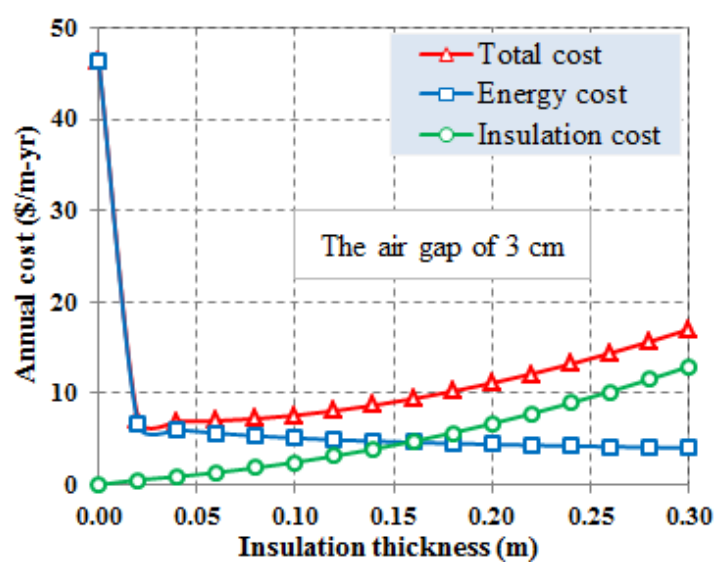

(c) $50 \mathrm{~mm}$ NPS

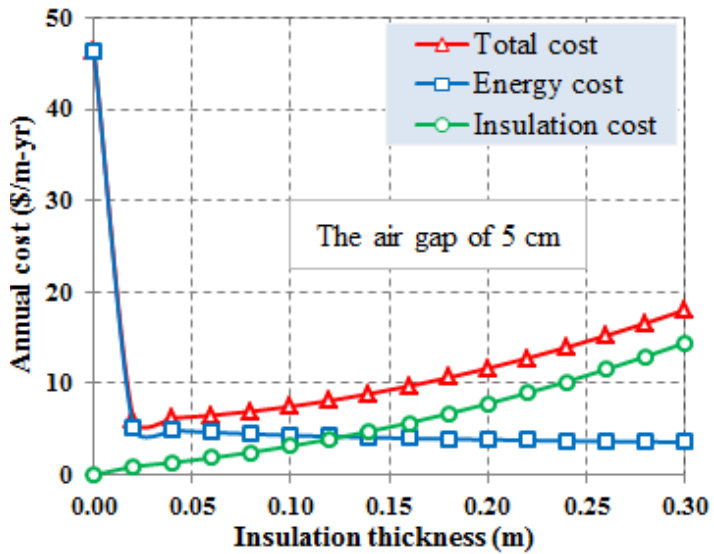

(d) $50 \mathrm{~mm}$ NPS

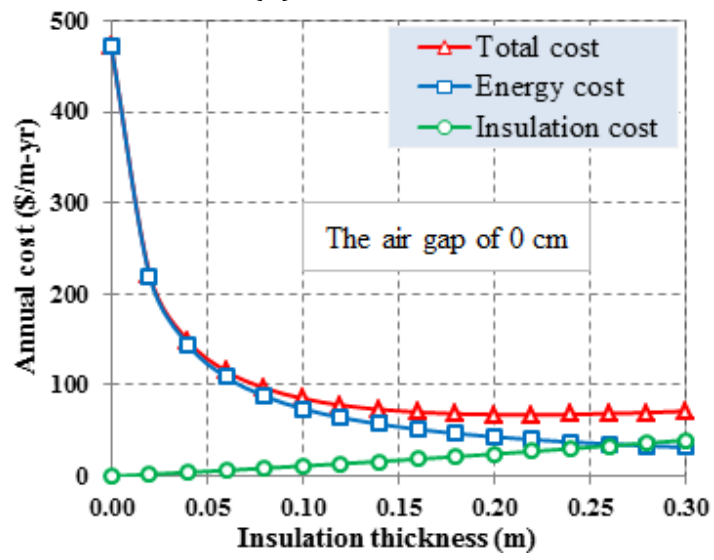

(e) $1000 \mathrm{~mm}$ NPS

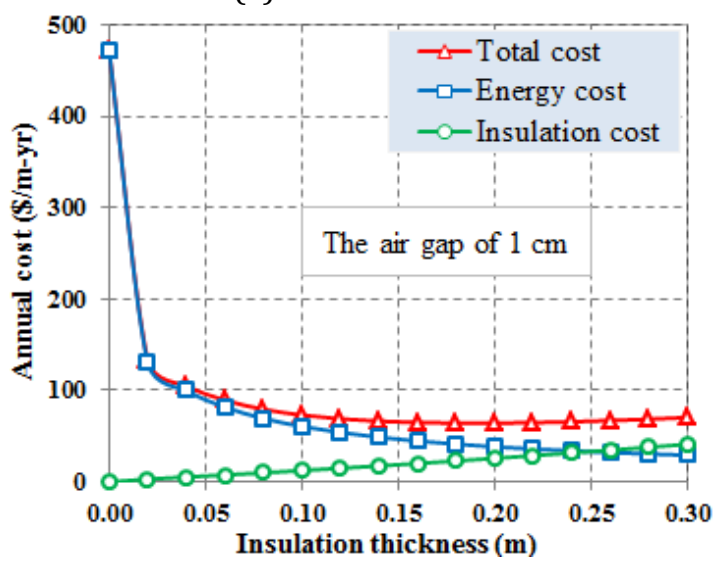

(f) $1000 \mathrm{~mm}$ NPS

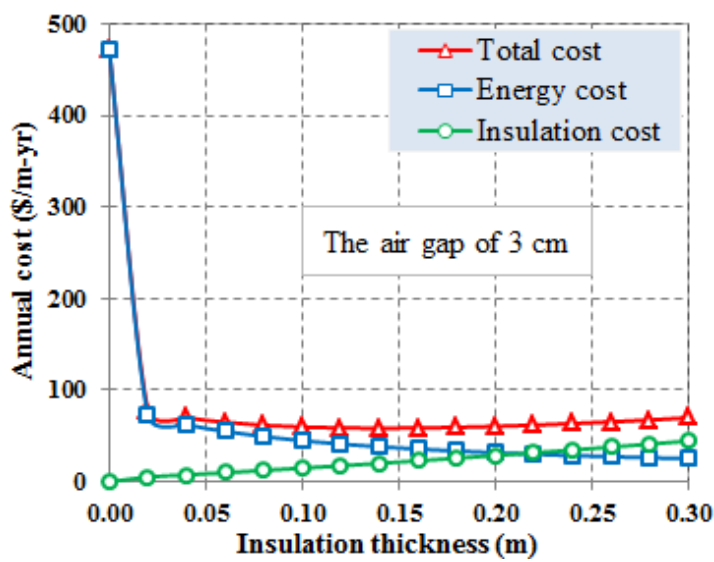

(g) $1000 \mathrm{~mm}$ NPS

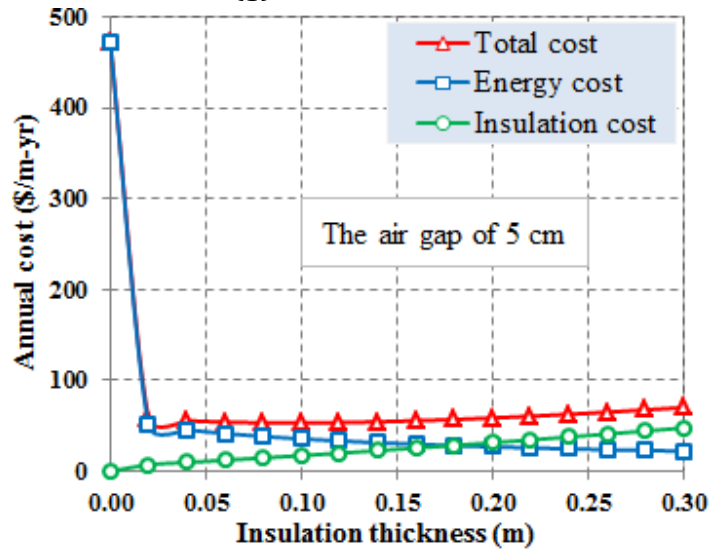

(h) $1000 \mathrm{~mm}$ NPS

Figure 2. Effect of insulation thickness on annual cost for (a)-(d) $50 \mathrm{~mm}$ and (e)-(h) $1000 \mathrm{~mm}$ NPSs in the air gaps of $0,1,3$ and $5 \mathrm{~cm}$.

The comparison of different pipe diameters on energy cost savings with insulation thickness for various air gap values is given in Fig. 3. As observed in all figures, with the use of insulation and air gap together the energy cost saving begins to increase. This increase reaches maximum value at the optimum insulation thickness. Later a reduction begins to occur. In Fig. 3-a showing the situation when an air gap is not used, as pipe diameters increase their energy cost savings appear to increase.

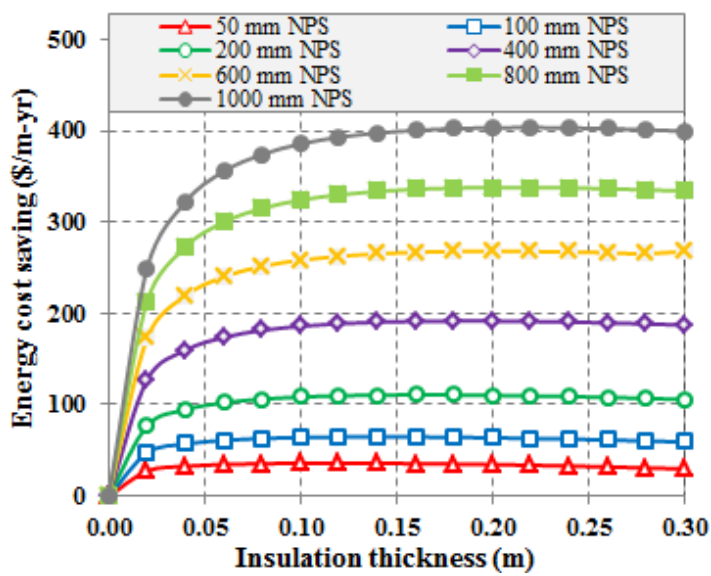

(a) 


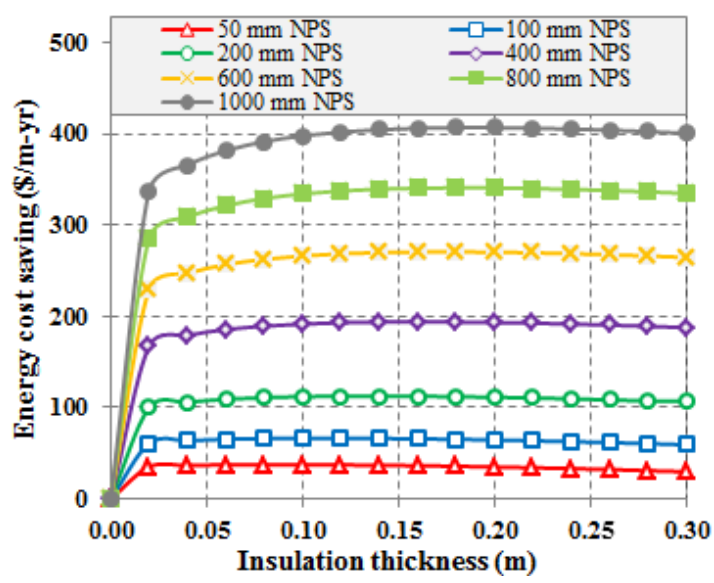

(b)

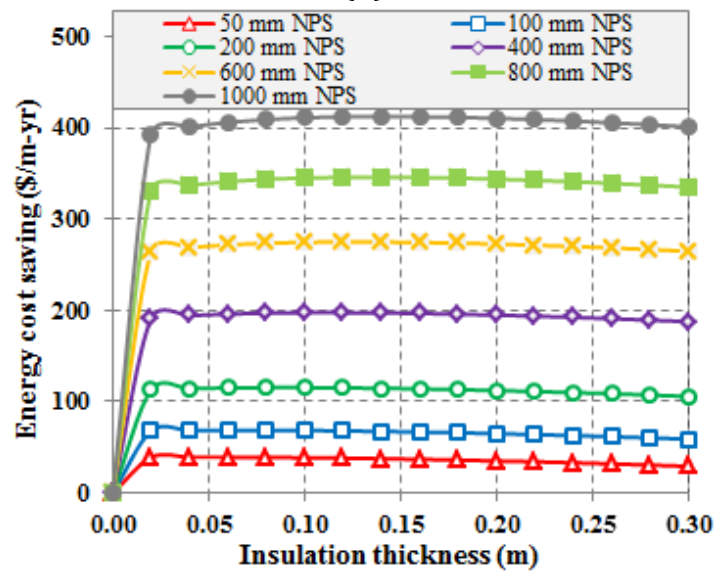

(c)

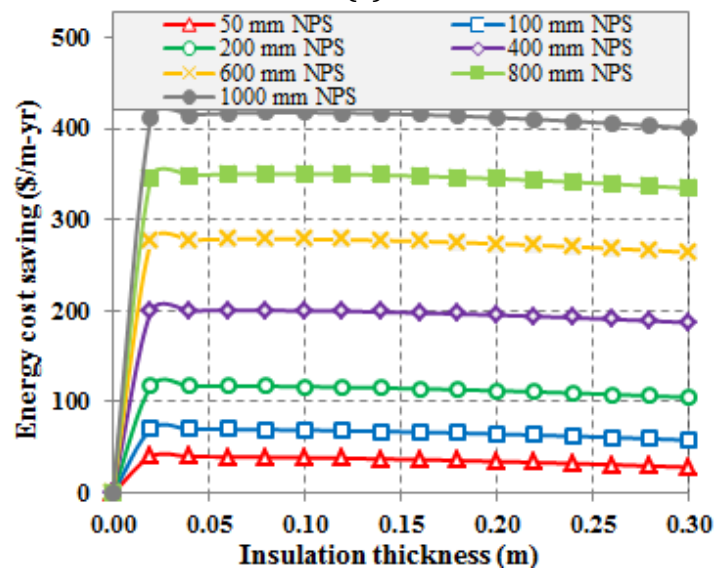

(d)

Figure 3. Effect of insulation thickness on energy cost saving for different nominal pipe sizes in the air gap of (a) $0 \mathrm{~cm}$, (b) $1 \mathrm{~cm}$, (c) $3 \mathrm{~cm}$ and (d) $5 \mathrm{~cm}$.

At optimum insulation thicknesses, the energy saving value for small diameter pipes of $50 \mathrm{~mm}, 100 \mathrm{~mm}$ and $200 \mathrm{~mm}$ is $35 \$ / \mathrm{m}-\mathrm{yr}, 63 \$ / \mathrm{m}-\mathrm{yr}$ and $108 \$ / \mathrm{m}-\mathrm{yr}$, respectively, while for large diameter pipes of $600 \mathrm{~mm}$, $800 \mathrm{~mm}$ and $1000 \mathrm{~mm}$, it is $261 \$ / \mathrm{m}-\mathrm{yr}, 329 \$ / \mathrm{m}-\mathrm{yr}$ and $393 \$ / \mathrm{m}$-yr. Thus, when only insulation is used as pipe diameters increase, the energy cost savings appear to increase exponentially. From Figs. 3-b, 3-c and 3-d illustrating the use of air gaps, the use of an air gap $(1 \mathrm{~cm})$ with small diameter pipes obtains highest energy cost savings. Contrary to this situation, for large diameter pipes no significant change is observed. For example, in Fig. 3-b air gap with $1 \mathrm{~cm}$ has energy cost savings for 50 $\mathrm{mm}$ and $1000 \mathrm{~mm}$ pipe diameters of $37 \$ / \mathrm{m}-\mathrm{yr}$ and 397 $\$ / \mathrm{m}$-yr. With $5 \mathrm{~cm}$ air gap these values are $40 \$ / \mathrm{m}$-yr and $412 \$ / \mathrm{m}$-yr (Fig. 3-d). It can be reached that the use of air gap with large and small diameter pipes did not significantly affect the energy cost savings.

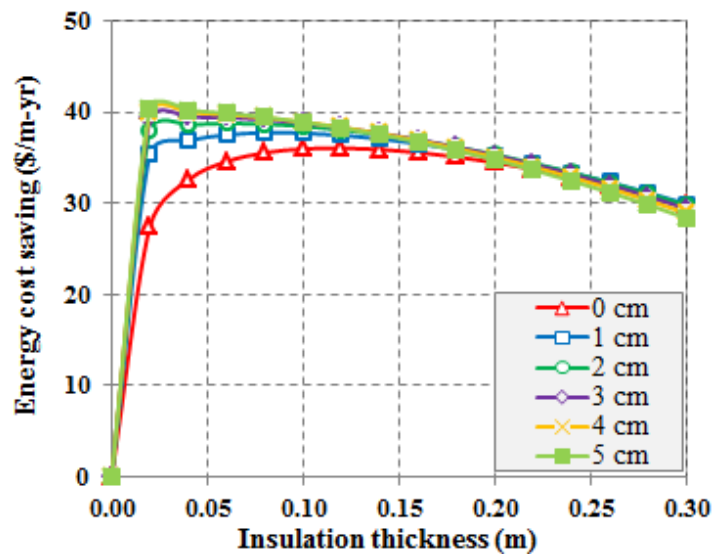

(a)

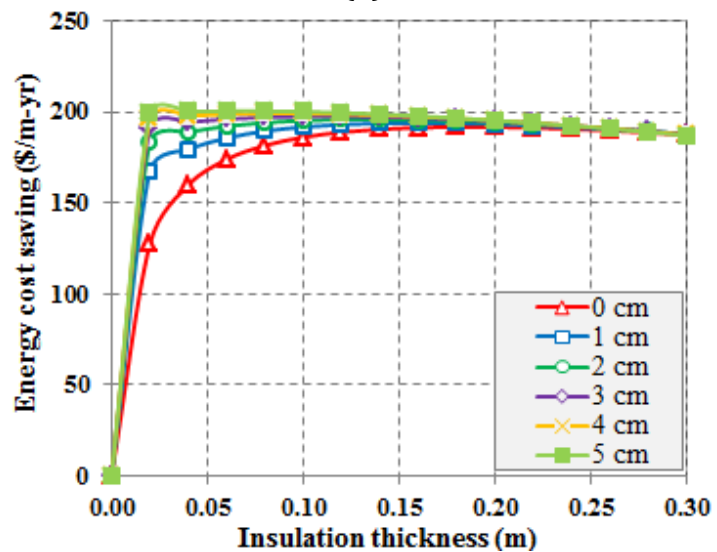

(b)

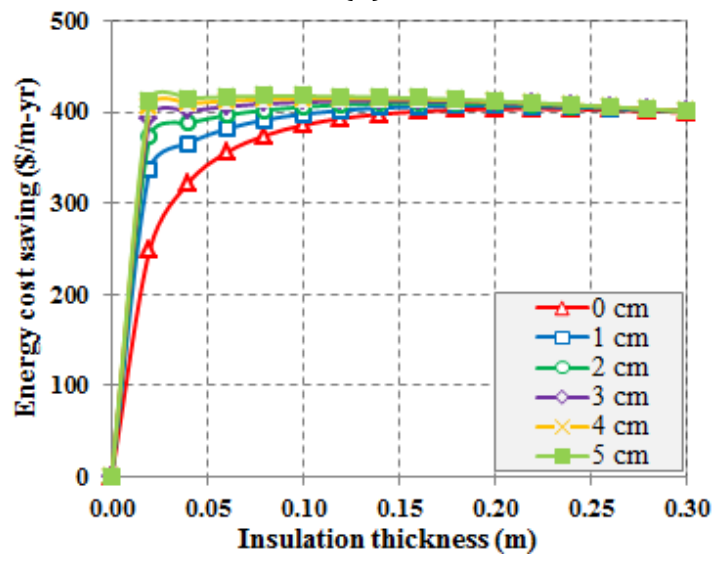

(c)

Figure 4. Effect of insulation thickness on energy cost saving in the range of 0 to $5 \mathrm{~cm}$ for the NPSs of (a) 50 $\mathrm{mm}$, (b) $400 \mathrm{~mm}$ and (c) $1000 \mathrm{~mm}$.

As seen in Fig. 4, a comparison of air gap values on energy cost savings with the insulation thickness for different pipe diameters is completed. For small diameter $50 \mathrm{~mm}$ 
pipes in Fig. 4-a, the air gap values from 0 to $5 \mathrm{~cm}$ have energy cost saving values of $35 \$ / m-y r, 37 \$ / m-y r, 38$ $\$ / \mathrm{m}-\mathrm{yr}, 39 \$ / \mathrm{m}-\mathrm{yr}, 39 \$ / \mathrm{m}-\mathrm{yr}$ and 40 \$/m-yr, respectively. For large diameter $1000 \mathrm{~mm}$ pipes, these values are $393 \$ / \mathrm{m}$-yr, 397 \$/m-yr, 401 \$/m-yr, 405 $\$ / \mathrm{m}-\mathrm{yr}, 408$ \$ $/ \mathrm{m}$-yr and 412 \$/m-yr (Fig. 4c). When Figs. 4-a, 4-b and 4-c are compared, as the air gap value increases, the energy saving amounts for large diameter pipes are wider than for small diameter pipes. Additionally, for all air gaps, as the pipe diameter increased, the energy cost saving curves become linear and parallel to the horizontal plane.

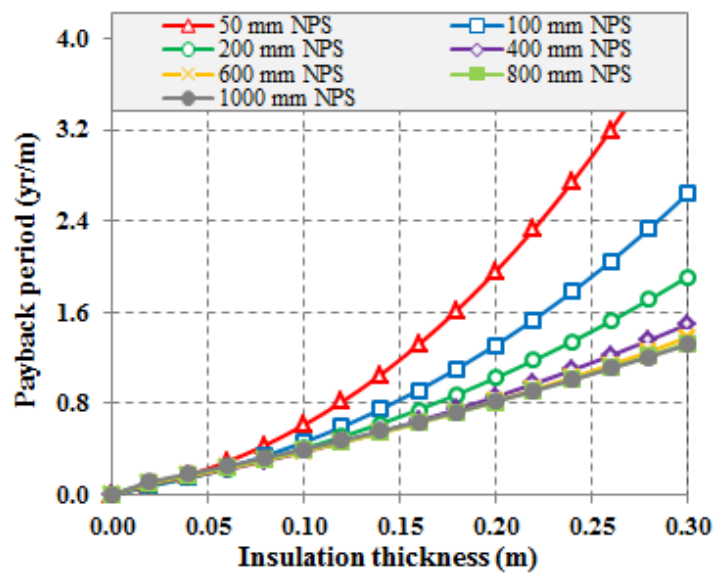

(a)

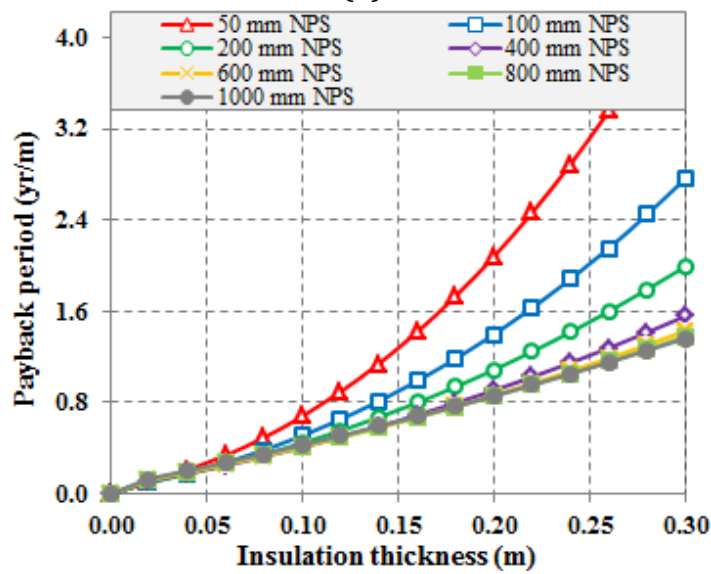

(b)

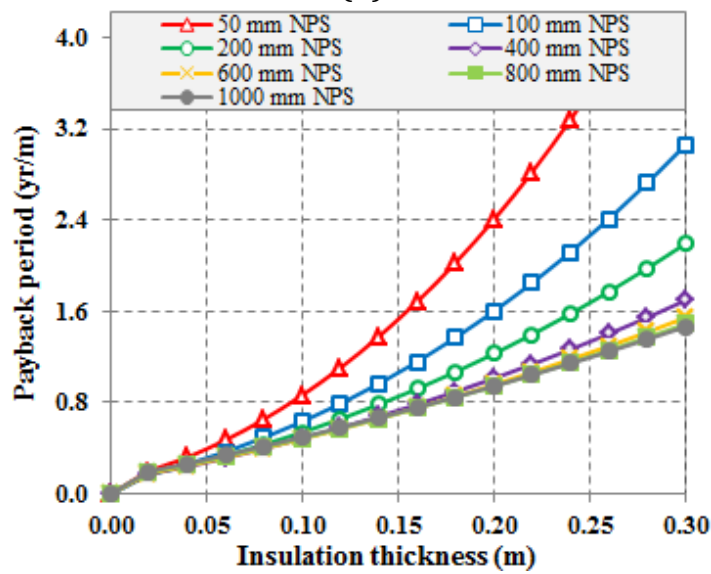

(c)

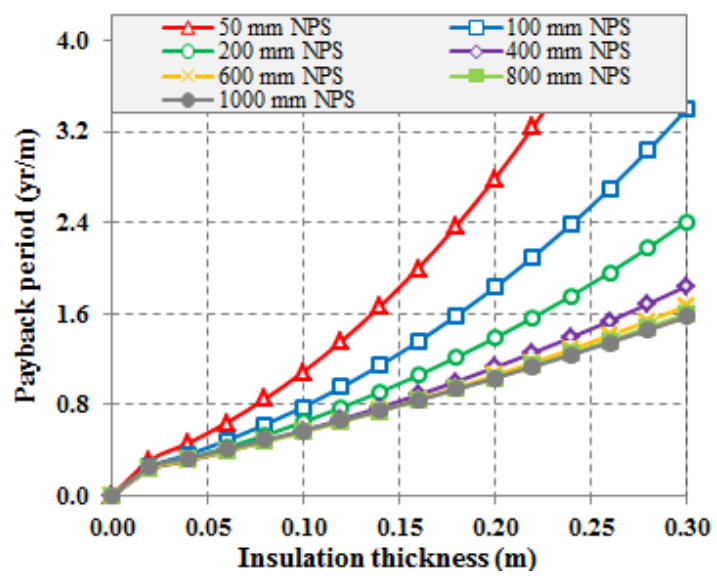

(d)

Figure 5. Effect of insulation thickness on payback period for different nominal pipe sizes in the air gap of (a) $0 \mathrm{~cm}$, (b) $1 \mathrm{~cm}$, (c) $3 \mathrm{~cm}$ and (d) $5 \mathrm{~cm}$.

Thus, for large diameter pipes the variation in insulation thickness with high air gap values does not affect the energy cost savings.

The variation in payback period according to insulation thickness with various air gap values and different pipe diameters is presented in Fig. 5. For the case where no air gap is used for pipe insulation, Fig. 5-a is drawn. As the insulation thickness increases for pipe diameters, the payback period appears to increase.

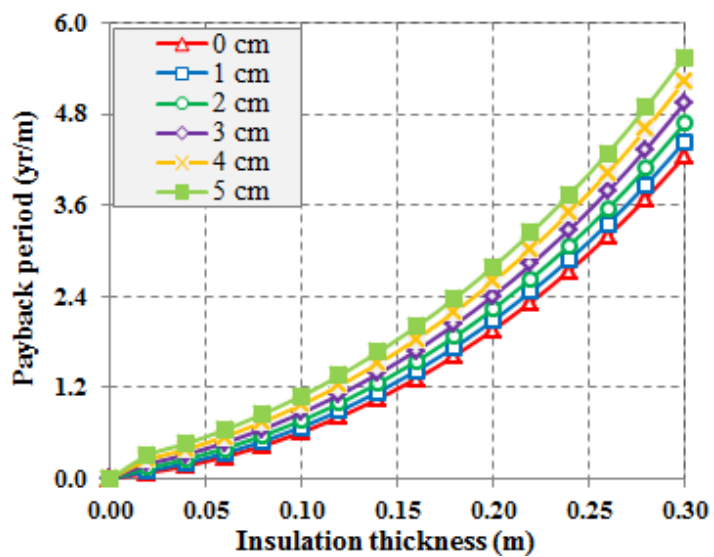

(a)

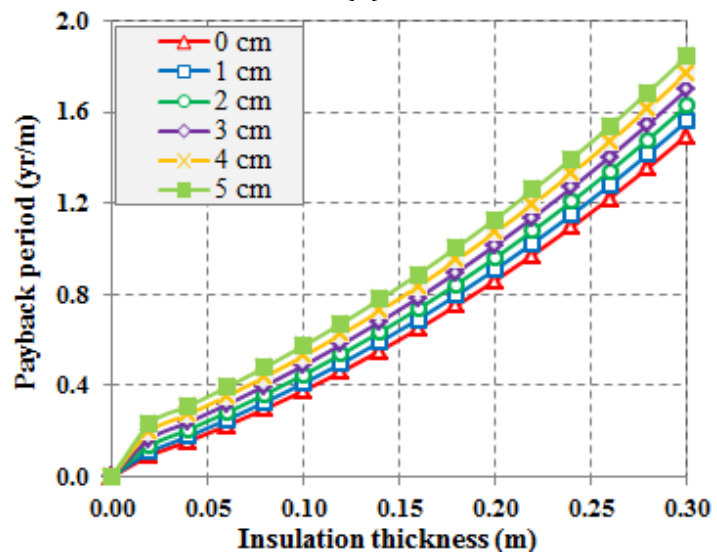

(b) 


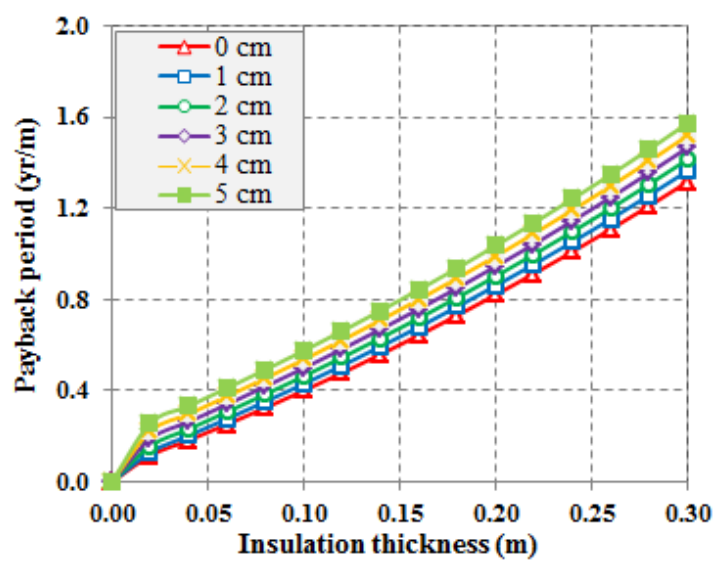

(c)

Figure 6. Effect of insulation thickness on payback period in the range of 0 to $5 \mathrm{~cm}$ for the NPSs of (a) 50 $\mathrm{mm}$, (b) $400 \mathrm{~mm}$ and (c) $1000 \mathrm{~mm}$.

This situation is explained by the energy cost savings occurring due to insulation application being counteracted by the increased insulation costs. For large diameter pipes the energy cost saving value of insulation is high, so the payback period shortens. For example, when $20 \mathrm{~cm}$ insulation thickness is used for a $1000 \mathrm{~mm}$ pipe, the payback period is 0.8 years, while for a small diameter $50 \mathrm{~mm}$ pipe this value is 1.9 years. Thus, the result of increasing insulation thickness increases the payback period for small diameter pipes compared to large diameter pipes. When air gaps with $1 \mathrm{~cm}, 3 \mathrm{~cm}$ and $5 \mathrm{~cm}$ are used, the payback period curves are shown in Figs. 5-b, 5-c and 5-d. In the figures, the variation in air gap for large diameter pipes does not affect the payback period. However, for small diameter pipes as the air gap increases the payback period increases by $15 \%$.

Fig. 6 shows the effects of air gap on payback period for different diameter pipes. On all figures as insulation thickness increases for all pipe diameters and air gap values, the payback period increases. In spite of this, for small diameter pipes (Fig. 6-a) the payback period for the use of insulation and air gap is 5.5 years. However, for large diameter pipes (Fig. 6-c) this value reached 1.6 years. In addition, as the air gap increased, the payback period lengthened.

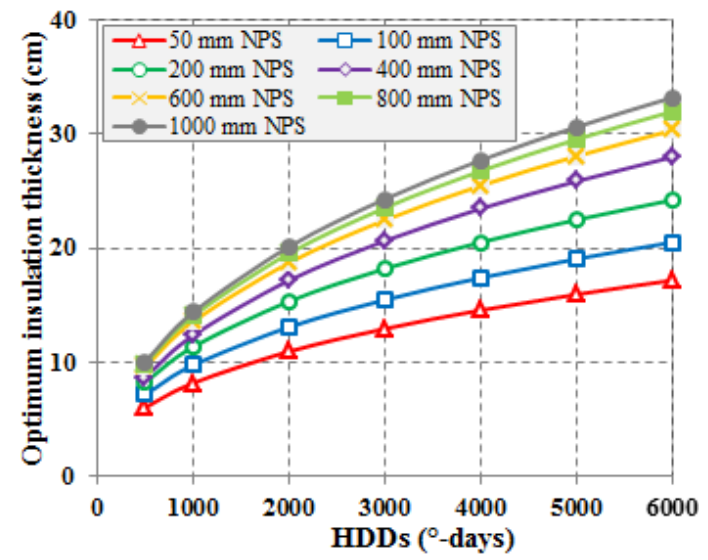

(a)

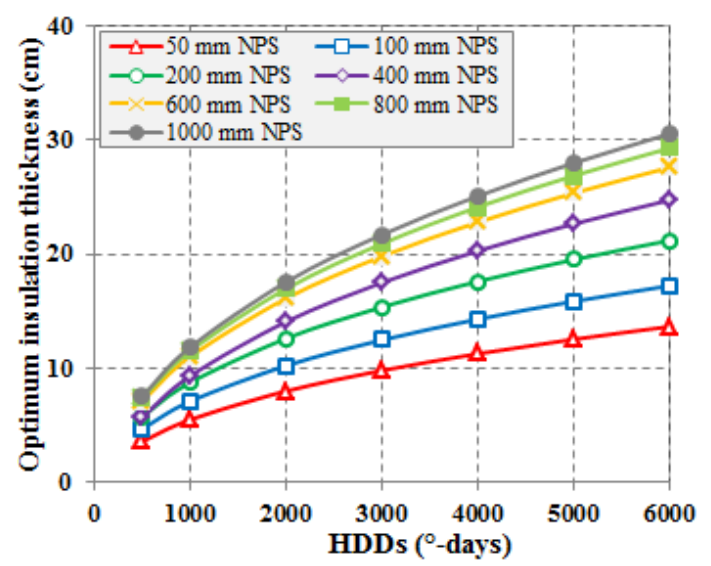

(b)

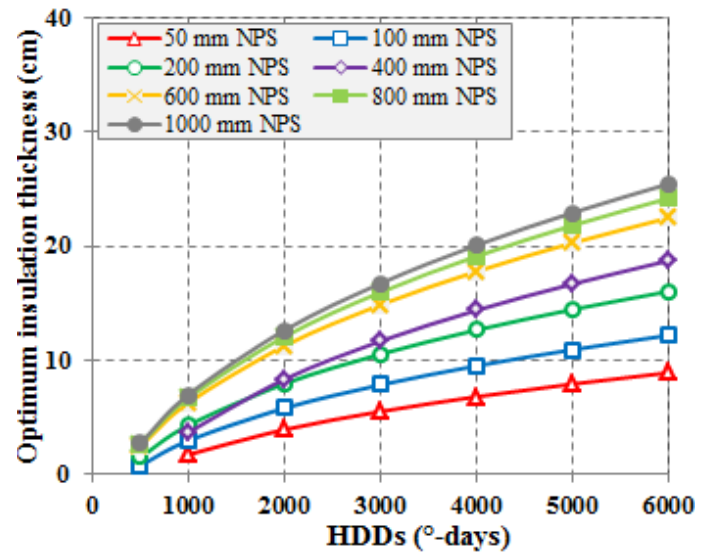

(c)

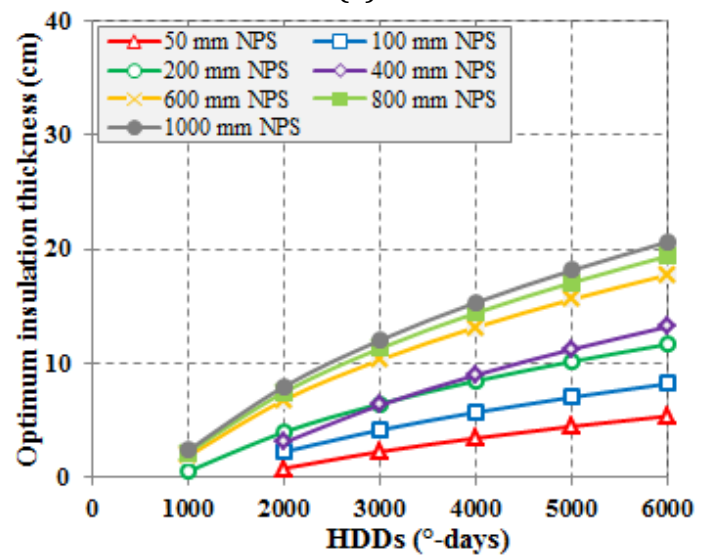

(d)

Figure 7. The change of the optimum insulation thickness depending on the heating degree-days for different nominal pipe sizes in the air gap of (a) $0 \mathrm{~cm}$, (b) $1 \mathrm{~cm}$, (c) $3 \mathrm{~cm}$ and (d) $5 \mathrm{~cm}$.

On Fig. 6-a initially the payback period curves for air gap value are close but as insulation thicknesses increase they begin to diverge. For large diameter pipes in Fig. 6c this situation is not the case. For small diameter $50 \mathrm{~mm}$ pipes (Fig. 6-a) the payback period curve is vertical and increases non-linearly, while for large diameter 1000 $\mathrm{mm}$ pipes (Fig. 6-c) the curves are horizontal and increase linearly. If the aim is to shorten the payback period, it is necessary to use an air gap and have insulation thickness at optimum value. 
The LCC analysis is considered for Afyon province. In practice we know that the optimum insulation thickness, energy cost saving and payback period can be selected in similar climatic zones in the world. Because there is a significant change between the maximum and minimum values of degree days in Turkey and in the world, the above mentioned parameters display significant differences from one region to another. Thus, pipe insulation application in this study can be used different cities or countries in different climatic regions. The variation in optimum insulation thickness according to degree day values for different pipe diameters with and without air gap is shown in Fig. 7. On all figures, as the degree day increases, the optimum insulation thickness is clearly seen to increase. For pipe insulation without air gap in Fig. 7-a moving from moderate climates to more severe climates, for all pipe diameters the optimum insulation thickness curves are positive increasing concave. In Fig. 7-b-7-d the curves are observed to curve more. For moderate climates the optimum insulation values in different pipe diameters are close to each other, while for severe climates they diverge. For $500^{\circ}$-days the optimum insulation thickness for all pipe diameters varied from 6 to $10 \mathrm{~cm}$ (difference $4 \mathrm{~cm}$ ), while for 6000 -days this varies from $17 \mathrm{~cm}$ to $33 \mathrm{~cm}$ (difference $16 \mathrm{~cm}$ ). Furthermore, for a $5 \mathrm{~cm}$ air gap, as seen in Fig. 7-d the optimum insulation thickness for pipe diameters in moderate climates varies at very low values from 0.1 to 2 $\mathrm{cm}$.

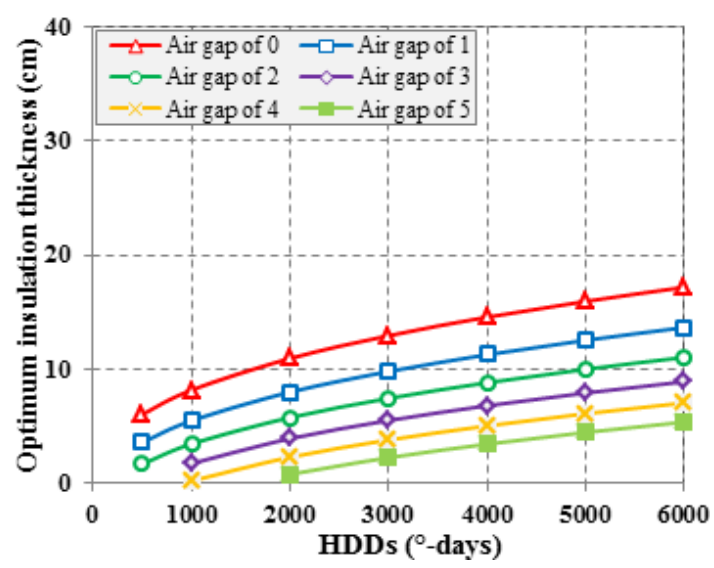

(a)

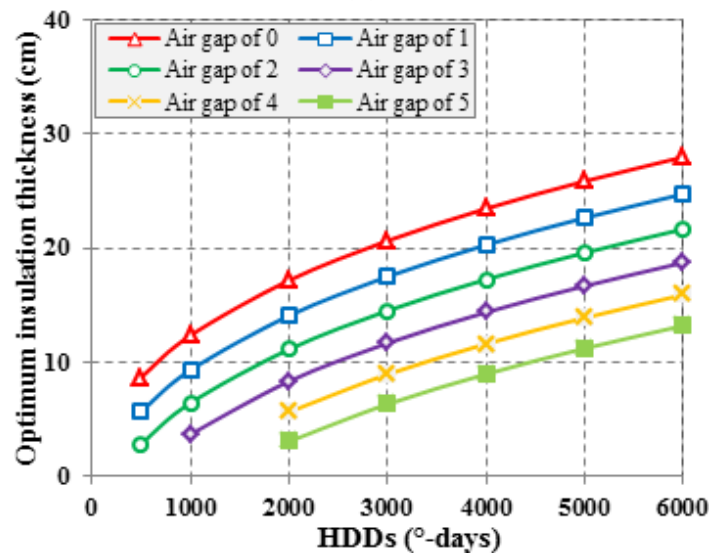

(b)

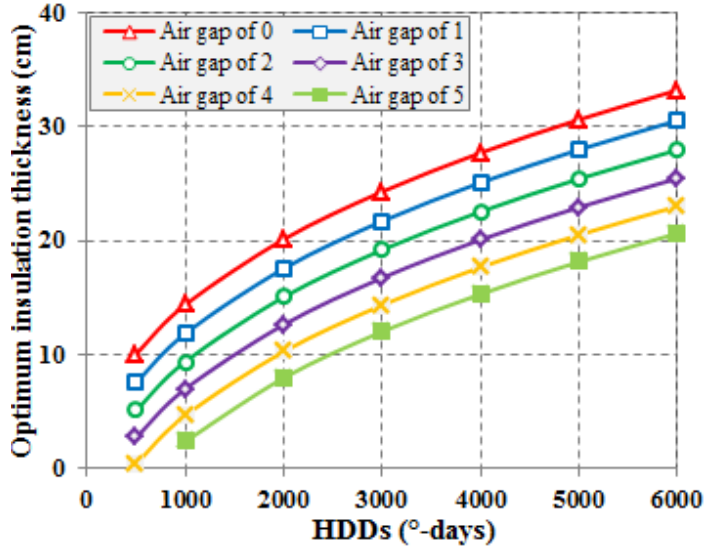

(c)

Figure 8. The change of the optimum insulation thickness depending on the heating degree-days in the range of 0 to $5 \mathrm{~cm}$ for the NPSs of (a) $50 \mathrm{~mm}$, (b) 400 $\mathrm{mm}$ and (c) $1000 \mathrm{~mm}$.

In Fig. 8 the variation in optimum insulation thickness according to degree day values when insulation and air gaps are used and not used for some pipe diameters is shown. On all graphs, it is obvious that the optimum insulation thickness increases with the increase of degree days. All optimum insulation thickness curves have a positive increasing concave down shape. As pipe diameters increase, these curves become more perpendicular.

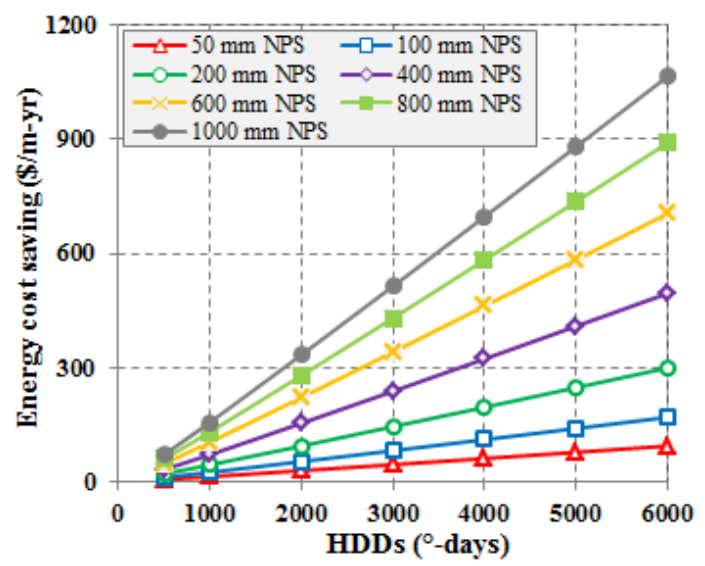

(a)

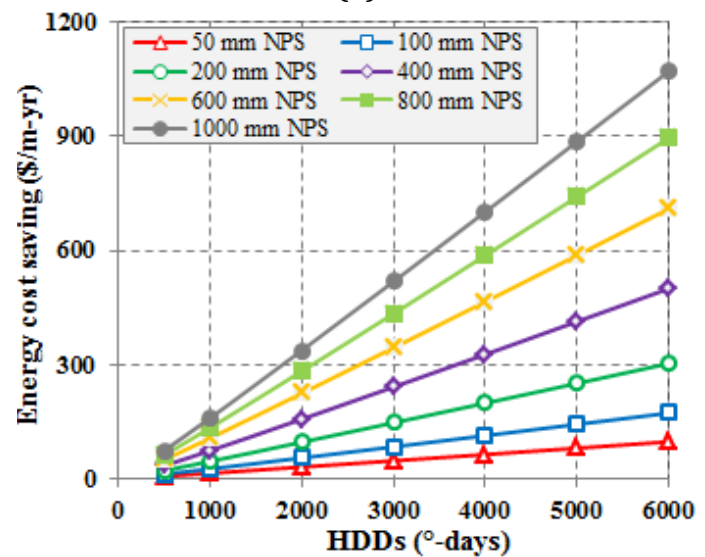

(b) 


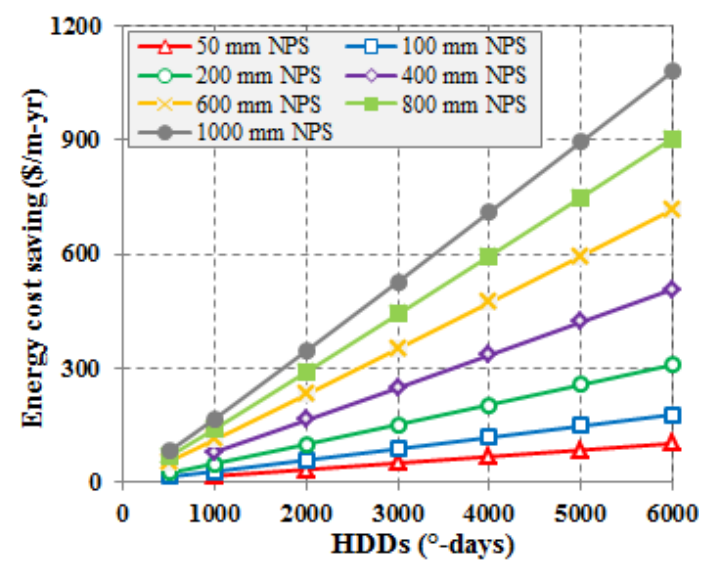

(c)

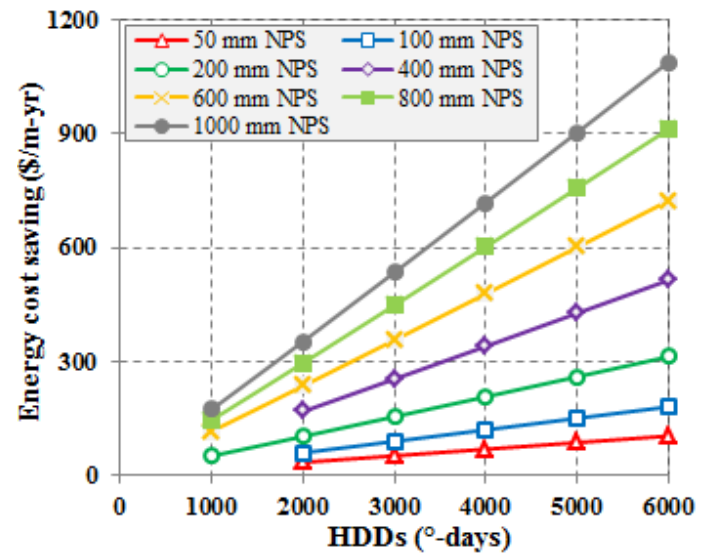

(d)

Figure 9. The change of the energy cost saving depending on the heating degree-days for different nominal pipe sizes in the air gap of (a) $0 \mathrm{~cm}$, (b) $1 \mathrm{~cm}$, (c) $3 \mathrm{~cm}$ and (d) $5 \mathrm{~cm}$.

For small diameter pipes, as seen on Fig. 8-a in moderate climates (500 ${ }^{\circ}$-days) for all air gap values the optimum insulation thickness varies from 0.1 to $6 \mathrm{~cm}$ (difference $5.9 \mathrm{~cm})$, while for severe climates $\left(6000^{\circ}\right.$-days) these values vary from 5 to $17 \mathrm{~cm}$ (difference $12 \mathrm{~cm}$ ). In Fig. 8$\mathrm{b}$ these values for moderate and severe climates vary from 3 to $9 \mathrm{~cm}$ (difference $6 \mathrm{~cm}$ ) and from 13 to $28 \mathrm{~cm}$ (difference $15 \mathrm{~cm}$ ). In Fig. 8-c these values vary from 0.3 to $10 \mathrm{~cm}$ (difference $9.7 \mathrm{~cm}$ ) and from 21 to $33 \mathrm{~cm}$ (difference $12 \mathrm{~cm}$ ). In severe climates, for large diameter pipes the use of air gap in addition to insulation is more advantageous.

The variation in energy cost savings for various pipe diameters based on heating degree days is given in Fig. 9. Here to compare different pipe diameters, energy cost savings changes for no air gaps and gaps of $1 \mathrm{~cm}, 3 \mathrm{~cm}$ and $5 \mathrm{~cm}$ are in turn drawn in Figs. 9-a-9-d. Initially when the figures are observed, all graphics appear similar. The energy cost savings appear to be directly proportional to pipe diameter and heating degree days. In other words, the variation in energy cost savings with heating degree days is not affected by air gap. On the other hand, as heating degree day values increase the energy cost savings for the increase in pipe diameters also increased. At $500^{\circ}$-days value, the energy cost savings for $50 \mathrm{~mm}$ and $1000 \mathrm{~mm}$ pipe diameters are $7 \$ / \mathrm{m}$-yr and $104 \$ / \mathrm{m}$ yr, while with $6000^{\circ}$-days value these values are $72 \$ / \mathrm{m}$ yr and $1064 \$ / m-y r$. Additionally in cold regions, energy cost savings become more important.

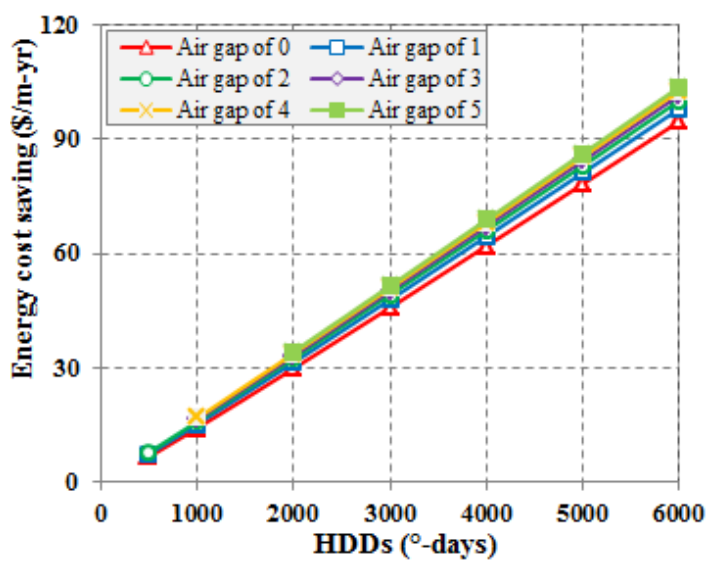

(a)

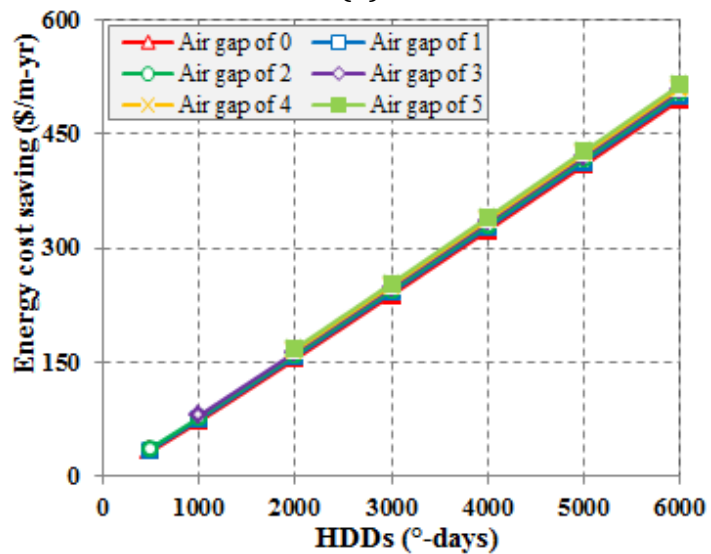

(b)

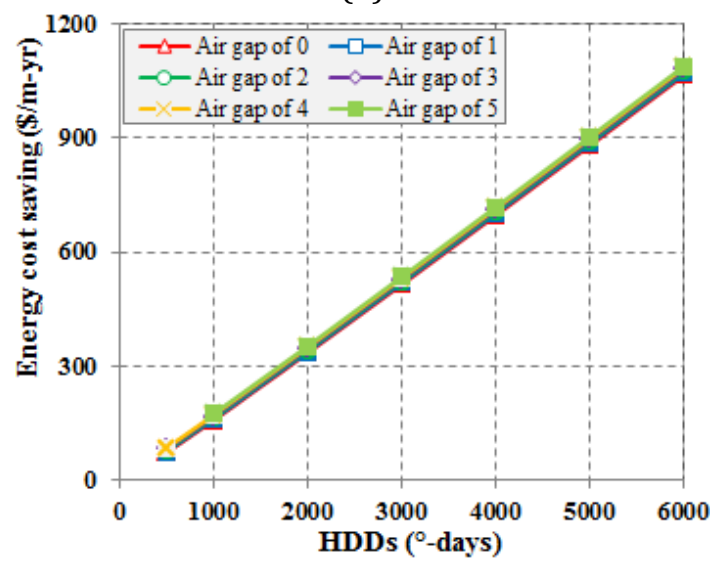

(c)

Figure 10. The change of the energy cost saving depending on the heating degree-days in the range of 0 to $5 \mathrm{~cm}$ for the NPSs of (a) $50 \mathrm{~mm}$, (b) $400 \mathrm{~mm}$ and (c) $1000 \mathrm{~mm}$.

According to Fig. 9, there is no effect of air gap on the variation in energy cost savings according to heating degree days and also this is more clearly shown in Fig. 10. The graphs for $50 \mathrm{~mm}, 400 \mathrm{~mm}$ and $1000 \mathrm{~mm}$ pipe diameters are drawn in Figs. 10-a-10-c. As seen on the figures, as the pipe diameters increase, energy cost 
saving curves for the air gap values overlap. For small diameter pipes and in cold regions, it may be said that air gap is effective on energy savings. However, in general heating degree days and air gap are not effective on energy cost savings. For example, for $500^{\circ}$-days in 50 $\mathrm{mm}$ pipe, the energy cost saving is nearly $7 \$ / \mathrm{m}-\mathrm{yr}$ for all air gap values, while for $6000^{\circ}$-days, this value for 400 $\mathrm{mm}$ and $1000 \mathrm{~mm}$ pipes varies from 95 \$/m-yr to 104 $\$ / \mathrm{m}$-yr (see Fig. 10-a). However, this variation is not observed on Fig. 10-c.

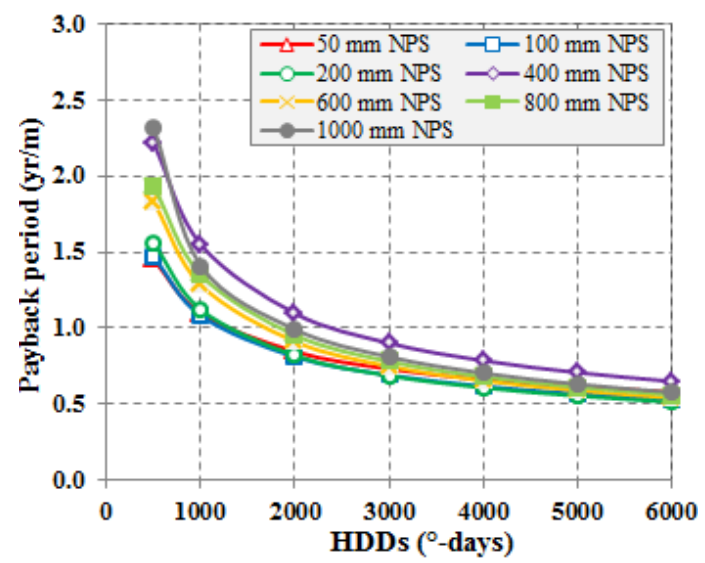

(a)

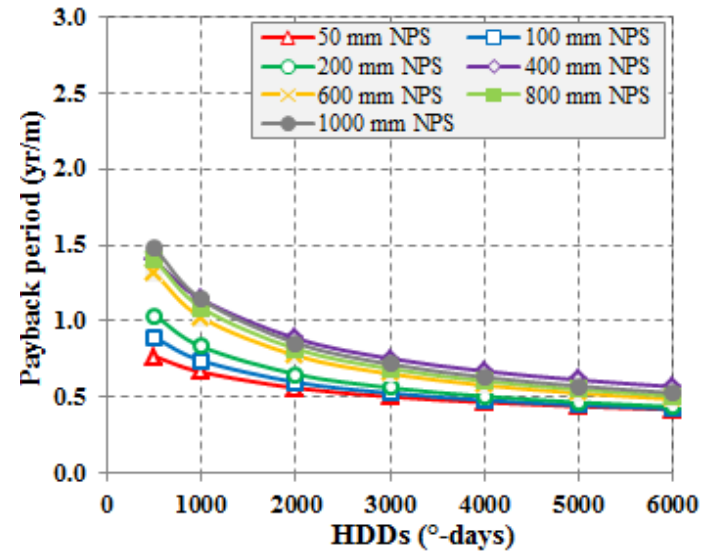

(b)

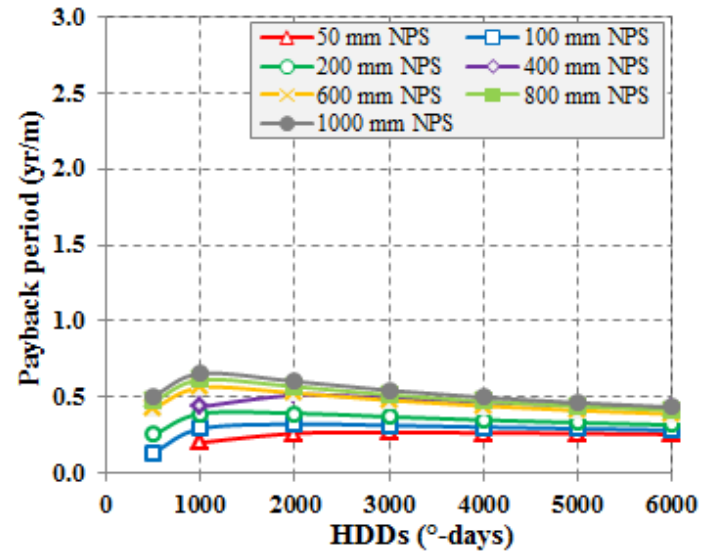

(c)

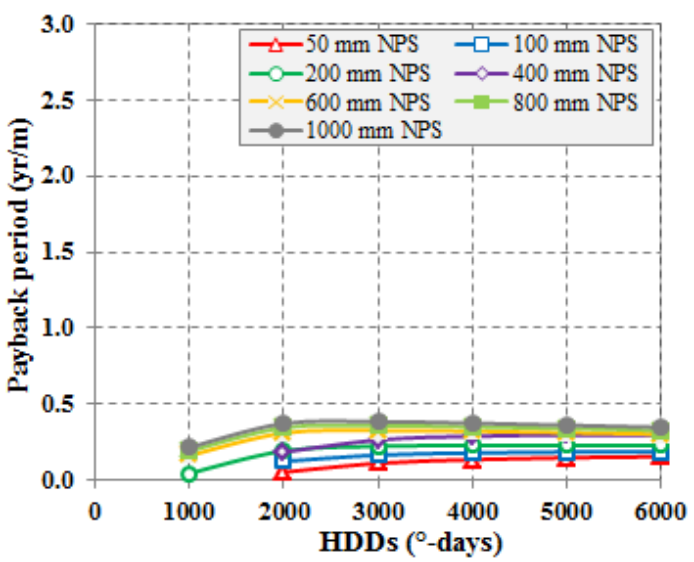

(d)

Figure 11. The change of the payback period depending on the heating degree-days for different nominal pipe sizes in the air gap of (a) $0 \mathrm{~cm}$, (b) $1 \mathrm{~cm}$, (c) $3 \mathrm{~cm}$ and (d) $5 \mathrm{~cm}$.

The changes on payback period of degree days for various pipe diameters and different air gap values are shown in Figs. 11 and 12, respectively. Here the change in payback period for various pipe diameters with and without air gap is given in Figs. 11-a-11-d. It is seen from the graphs that as air gap values and heating degree day values increase and contrarily as pipe diameters decrease, the payback period reduces. For $500^{\circ}$-days the payback period is long, while for $6000^{\circ}$-days the payback period reduces. As heating degree day increase, for 50 $\mathrm{mm}$ and $1000 \mathrm{~mm}$ pipe diameters without air gap (see Fig. $11-a)$, the payback period reduces by $75 \%$ and $60 \%$, while for $5 \mathrm{~cm}$ air gap at these pipe diameters (see Fig. $11-d)$ the payback period reduction is $1 \%$ and $7 \%$. This shows that in cold climates insulation application is more advantageous. The change in payback period for pipe diameters with different air gap values is shown in Figs. 12-a-12-c. In these figures similar results are obtained. The payback period is linked to heating degree days and air gap values. The payback period reduces as heating degree day increase.

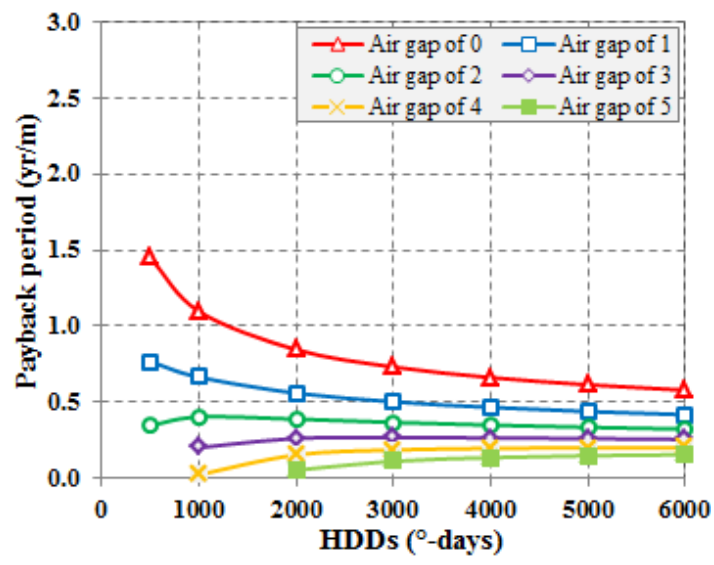

(a) 


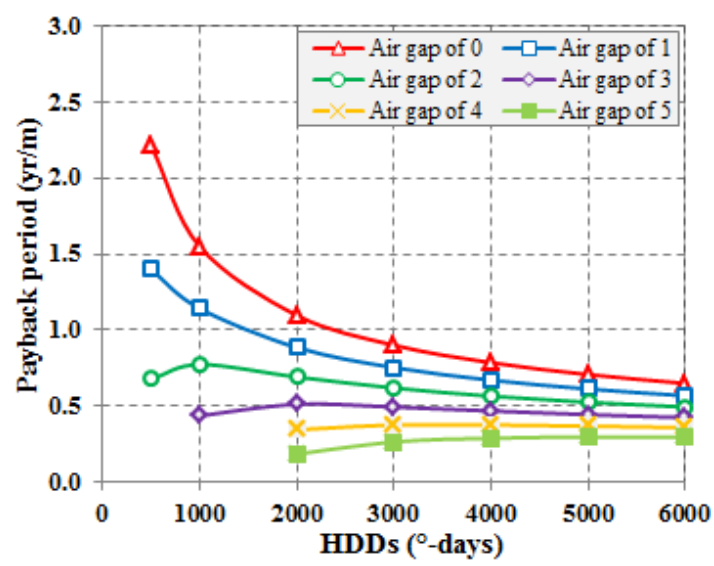

(b)

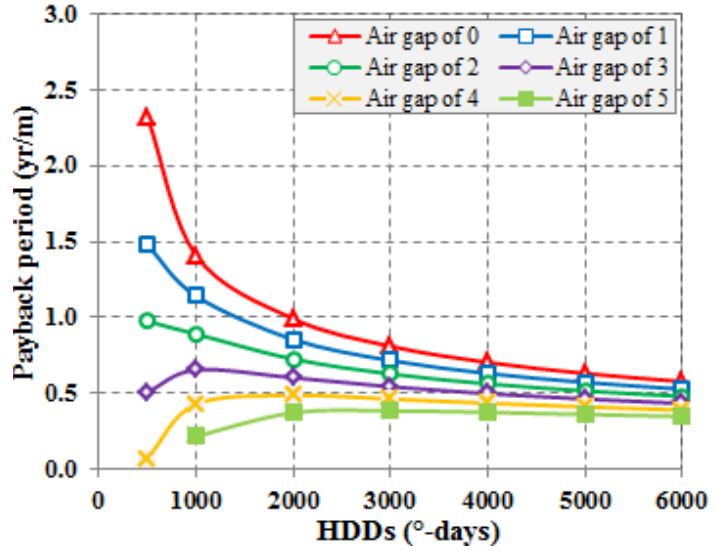

(c)

Figure 12. The change of the payback period depending on the heating degree-days in the range of 0 to $5 \mathrm{~cm}$ for the NPSs of (a) $50 \mathrm{~mm}$, (b) $400 \mathrm{~mm}$ and (c) $1000 \mathrm{~mm}$.

For example, for small pipe diameters $(50 \mathrm{~mm}$ ) (see Fig. 12 -a) as the air gap increases from 0 to $5 \mathrm{~cm}$ with $500^{\circ}$. days the payback period reduces from $1.5 \mathrm{yr} / \mathrm{m}$ to 0.2 $\mathrm{yr} / \mathrm{m}$. For $6000^{\circ}$-days, this payback period reduces from $06 \mathrm{yr} / \mathrm{m}$ to $0.2 \mathrm{yr} / \mathrm{m}$. For large diameter pipes (see Fig. 12-c) under moderate and cold conditions the payback periods are between $2.3-0.4 \mathrm{yr} / \mathrm{m}$ and $0.6-0.3 \mathrm{yr} / \mathrm{m}$. This situation shows that in moderate regions the use of an air gap reduces insulation costs which shorten the payback period. Therefore, it is understood that in moderate climates the use of an air gap is necessary and in cold climates the use of an air gap does not have a significant effect.

\section{Conclusion}

This article presents a theoretical study for calculating parameters such as optimum insulation thickness, energy cost, energy saving and payback period when using air gap and insulation in pipes in mechanical installations. In addition, the above mentioned parameters have been comparatively assessed for cold, mild and warm climate conditions, various pipe diameters and various air gap values. For this purpose, life cycle cost analysis with heating day degree has been used. Afyon/Turkey climate conditions have been selected as case study and fuel-oil and EPS insulation material have been used. The results of the study shown that the use of insulation and air gap in large diameter pipes lowers the total annual cost by $81 \%$ and $39 \%$, while for small diameter pipes this value is reduced by $64 \%$ and $42 \%$. The use of insulation for large diameter pipes and air gap for small diameter pipes ensure significant reductions in total annual costs. When insulation is used, as the pipe diameter increases energy costs saving values have been observed to increase exponentially. However, the use of air gap for small and large diameter pipes does not significantly affect energy cost savings. As the air gap value increases, the energy cost saving is greater for large diameter pipes compared to small diameter pipes. The result of increasing insulation thickness increases the payback period for small diameter pipes more compared to large diameter pipes. If the payback period is to be shortened for small diameter pipes, it is sufficient to use optimum insulation thickness instead of air gap. Heating degree days are significantly different from one region to another. The increase in heating degree days increases optimum insulation thickness. In severe climates, for large diameter pipes the use of air gap in addition to insulation is more advantageous. Within the variation of energy cost savings with heating degree day, it is clear that there is no air gap effect. As the air gap value and heating degree day values increase and contrarily as pipe diameters reduce, the payback period reduces. In moderate climates the use of air gap is necessary and in cold climates the use of air gap has no significant effect. In cold climates application of insulation is more advantageous.

\section{References}

[1]. Kecebas, A., Alkan, M.A. and Bayhan, M., "Thermoeconomic analysis of pipe insulation for district heating piping systems", Applied Thermal Engineering, Vol. 31, 3929-3937, 2011.

[2]. Mohsen, M.S. and Akash, B.A., "Some prospects of energy saving in buildings", Energy Conversion and Management, Vol. 42, 1307-1315, 2001.

[3]. Suman, B.M. and Srivastava, R.K., "Effect of air gap on thermal performance of composite wall section," Indian Journal of Science and Technology, Vol. 1, 1-4, 2008.

[4]. Mahlia, T.M.I. and Iqbal, A., "Cost benefits analysis and emission reductions of optimum thickness and air gaps for selected insulation materials for building walls in Maldives”, Energy, Vol. 35, 2242-2250, 2010.

[5]. Kurt, H., "The usage of airgap in the composite wall for energy saving and air pollution", Environmental Progress \& Sustainable Energy, Vol. 30, 450-458, 2011.

[6]. Dasdemir, A., "Economical and environmental analysis of the usage of air gap in the composite wall", Electronic Journal of Machine Technologies, Vol. 8, 49-61, 2011.

[7]. Ridouane EH, Bianchi MVA. Thermal performance of uninsulated and partially filled wall cavities. ASHRAE Annual Conference Montreal, Quebec, June 25-29, 2011.

[8]. Mahlia, T.M.I., Ng, H.M., Olofsson, T. and Andriyana, A., "Energy and cost savings of optimal thickness for selected insulation materials and air gaps for building walls in tropical climate", Energy Education Science and Technology Part A: Energy Science and Research, Vol. 29, 597-610, 2012.

[9]. Cai, S. and Cremaschi, L. "An experimentally validated model to predict the thermal conductivity 
of closed-cell pipe insulation systems with moisture", ASHRAE Conference Paper No: NY-14-C090, ASHRAE Winter Conference, New York, 2014.

[10]. Faris, S.S., Chaichan, M.T., Sachit, M.F. and Jaleel, J.M., "Simulation and numerical investigation of the effect of air gap thickness on trombe wall system", International Journal of Application or Innovation in Engineering \& Management, Vol. 3, 159-168, 2014.

[11]. Erturk, M., "A new approach to calculate the energy saving per unit area and emission per person in exterior wall of building using different insulation materials and air gap", Journal of the Faculty of Engineering and Architecture of Gazi University, Vol. 31, 395-406, 2016.

[12]. Kayfeci, M., "Determination of energy saving and optimum insulation thicknesses of the heating piping systems for different insulation materials", Energy and Buildings, Vol. 69, 278-284, 2014.

[13]. Basogul, Y. and Kecebas. A. "Economic and environmental impacts of insulation in district heating pipelines", Energy, Vol. 36, 6156-6164, 2011.

[14]. Kecebas, A., "Determination of optimum insulation thickness in pipe for exergetic life cycle assessment", Energy Conversion and Management, Vol. 105, 826-35, 2015.

[15]. Kecebas, A., "Determination of insulation thickness by means of exergy analysis in pipe insulation", Energy Conversion and Management, Vol. 58, 76-83, 2012.

[16]. Erturk, M., “Optimum insulation thicknesses of pipes with respect to different insulation materials, fuels and climate zones in Turkey", Energy, Vol. 113, 991-1003, 2016.

[17]. Holman, J.P., Heat transfer, 7th ed., McGraw-Hill Book Co., New York, USA, 1992.

[18]. Ashrae, Handbook-Fundamentals, "Heat transfer", Atlanta: ASHRAE, Chapter 22, p. 22.1-22.21, 1989. 